\title{
A Study of Tang-dynasty Transformation Tableaux of the Sütra of the Medicine Buddha from Dunhuang
}

\author{
Che-Hsuan Chen
}

Medicine Buddha is one of the principal Buddhas in the Buddhist pantheon. His Sanskrit name, Bhaișajyaguru, literally means "Medicine Master (Ch. 藥師 Yaoshi; Jp. 薬師 Yakushi).” In the Buddhist pantheon, Medicine Buddha is well known for his power to heal all illnesses on earth. When he was a bodhisattva, he made the Twelve Great Vows for the welfare of sentient beings as well as a promise to prevent the Nine Forms of Violent Death. His cult centers around the achievement of health and longevity in this life. On achieving Buddhahood, he presided over the Eastern Pure Land of Pure Lapis Lazuli, which is covered by the dark blue gemstone, lapis lazuli. His flawless Pure Land is free from suffering and evil. It is comparable in every way to the palaces and pavilions constructed of the seven precious substances of the Western 
Pure Land of Amitābha. ${ }^{1}$ He is attended by two bodhisattvas symbolizing the light of the sun and the light of the moon respectively, and his Pure Land is guarded by the Twelve Generals.

The textual and visual representations of this Buddha did not exist in ancient India, the homeland of Buddhism. Instead, these materials can be traced back to Central Asia, where the worship of the Medicine Buddha first developed. ${ }^{2}$ The cult of Medicine Buddha then spread into China along the Silk Road in the fourth century. ${ }^{3}$ As it became one of the most popular and venerated healing deities, the cult of Medicine Buddha reached the Korean peninsula in the fifth century and finally entered Japan at the end of the sixth century. ${ }^{4}$

In China, Medicine Buddha has had a faithful following since the sixth century. There are numerous art pieces about Medicine Buddha, such as paintings and statues of his image or his preaching assembly. Considering the plentiful amount of art works

1 Takakusu Junjirō 高楠順次郎 and Watanabe Kaigyoku 渡辺海旭 ed., Taishō shinshū Daizōkyō 大 正新脩大蔵経, 100 vols. (Tōkyō: Taishō issai-kyō kanko kai, 1922-34), [hereafter T.] no. 450, Vol. 14, p. 405c.

2 Alexander Soper, Literary Evidence for Early Buddhist Art in China (Ascona: Artibus Asiae Publication, 1959), p. 173. Also in Raoul Birnbaum, The Healing Buddha (Boulder: Shambhala, 1979), pp. 54-60.

3 Birnbaum, p. 25.

4 Yui Suzuki, Medicine Master Buddha: the iconic worship of Yakushi in Heian Japan (Boston: Brill, 2012), p. 1. 
depicting Medicine Buddha in China, it is necessary to focus on specific examples. Among these art pieces, the illustrations of the Sütra of the Medicine Buddha in murals or scrolls have the richest pictorial content. As these forms have changed over time, it is worth investigating. Most of the existing illustrations of the Sütra of the Medicine Buddha were found at Dunhuang. Not counting the single images and paintings of the Medicine Buddha preaching to an assembly, there are still more than ninety illustrations of the Sütra of the Medicine Buddha in the Dunhuang Grottoes. The cult of Medicine Buddha at Dunhuang is reflected in the existence of these illustrations. This paper will discuss the pictorial development of the Medicine Buddha illustrations at Dunhuang during the Tang Dynasty (618-907), a period during which the worship of Medicine Buddha prospered. Through the survey of pictorial details shown in these illustrations, the meaning and function of these paintings will be clarified.

The Chinese term for this category of illustrations (transformation tableaux of sūtras) is called jingbian 經變. ${ }^{5}$ According to the monastic culture in the Tang Dynasty, there were both textual and visual jingbian called bianwen 變文 and bianxiang 變相, respectively. Bianwen, as transformed texts of sütra, is used for popular storytelling (俗

5 Victor Mair writes "bian was already firmly established in the Buddhist technical vocabulary," in "Records of Transformation tableaux (pien-hsiang)," T'oung Pao 72, no. 1/3 (1986), p. 14. Also see definition by Joji Okazaki, translated by Elizabeth ten Grotenhuis, Pure Land Buddhist Painting (New York: Kodansha Amer Inc., 1977), p. 29. 
講). Bianxiang, which literally means "transformation tableau of sütra," is more complicated since the meaning of the term bianxiang has changed over time. Most of the bianxiang paintings were not used in storytelling. These paintings were associated with illustrating the complex contents of sütras and were not the same as individual icons. ${ }^{6}$ Mair states that one single "layout ( $p u$ 鋪)" could depict more than one event. ${ }^{7}$ The depictions of the Pure Lands with preaching scenes based on sütras became more popular in the Tang Dynasty. The term bian or bianxiang was mentioned frequently in documents that recorded the patronage of construction and decoration for Dunhuang caves. Within the complex composition of a bianxiang mural, everything in the picture is arranged in a specific order. Viewed from a bird's-eye perspective, the preaching scene is in the center of the painting, and set within a horseshoe-shaped architectural complex. The Buddhas and bodhisattvas sit on the main platform with a hierarchical and symmetrical arrangement. Below these platforms are the terraces and porches with balustrades floating on a lotus pond. These terraces and porches are filled with deities, musicians, and dancers. This is the Pure Land that Tang people imagined. Sometimes, there are vertical columns at the two ends with smaller scenes describing more sections of the sutras next to the Pure Land scene.

6 Hung Wu, "What Is Bianxiang? - On the Relationship between Dunhuang Art and Dunhuang Literature," Harvard Journal of Asiatic Studies 52, no. 1 (1992), pp. 116-119. Mair, p. 43.

7 Mair, p. 12. 
Different versions and contents of the sūtra

The primary Sütra of the Medicine Buddha has been translated into Chinese many times. There are at least five translations related to the Dunhuang materials. In the fourth century, Śrimitra 帛尸梨密多羅 translated the first one, which is the twelfth and final chapter of the text named Sütra Spoken by the Buddha on the Abhiseka Which Eliminates Faults of the Past and Confers Freedom from Birth and Death (Ch. Fo shuo guan ding ba chu guo zui sheng si de du jing 佛說灌頂拔除過罪生死得度經). ${ }^{8}$ A similar version titled Sütra on the Master of Healing of Lapis Lazuli Radiance (Ch. Yaoshi liu li guang jing 藥師琉璃光經) is attributed to the monk Huijian 慧簡 of the Liu Song period (420-479) and was translated in 457 CE. Huijan's version is not collected in the Chinese Buddhist Canon but survives in a hand-copied format in Dunhuang. Huijian's version is almost the same as Śrīmitra's version. Based on the records in the Sui Dynasty, Lee Yu-min argued that Śrīmitra's version is a revised edition of Huijian's version. ${ }^{9}$ There remain one hundred and eighteen copies for the two

8 T. no. 1331, vol. 21.

9 Lee Yu-min, “Dunhuang yaoshi jingbian yenjiu,” Gu gong xue shu ji kan 7, no. 3 (1990), pp. 3-5. 
versions in Dunhuang. ${ }^{10}$

The third version, titled Sütra Spoken by the Buddha on the Fundamental Vows of the Master of Healing (Ch. Fo shuo Yaoshi rulai benyuan jing 佛說藥師如來本願經), was translated by Dharmagupta 達摩笈多 (?-619) in 615 CE. ${ }^{11}$ Only one manuscript found in Dunhuang was based on Dharmagupta's version. ${ }^{12}$ In $650 \mathrm{CE}$, the master of Tripitaka, Xuanzang 玄焋 (602-664), translated the Sütra on the Merits of the Fundamental Vows of the Masters of Healing of Lapis Lazuli Radiance (Ch. Yaoshi liuli guang rulai benyuan gongde jing 藥師琉璃光如來本願功德經). ${ }^{13}$ One hundred and forty three manuscript copies of Xuanzang's version have been recovered from Dunhuang. It had been copied the most times among the five versions in Dunhuang. ${ }^{14}$ More than half of these are dated from the seventh and eighth centuries. ${ }^{15}$ Yijing 義淨 (635-713) translated the Sütra on the Merits of the Fundamental Vows of the Seven

10 Based on Birnbaum's calculation, about thirty eight copies of Śrīmitra's version were found at Dunhuang, dated to the sixth and seventh centuries. See Birnbaum, pp. 55-72. Lee's number comes from the combination of Śrimitra's and Huijian's versions and disregards the producing period. See Lee, p. 7.

11 T. no. 449, vol. 14.

12 Lee, p. 7.

13 T. no. 450, vol. 14.

14 Lee, p. 7.

15 Birnbaum, p. 73. 
Buddhas, the Masters of Healing of Lapis Lazuli Radiance (Ch. Yaoshi liuli guang qifo benyuan gongde jing 藥師琉璃光七佛本願功德經) in $707 \mathrm{CE} .{ }^{16}$ Only one copy of this version has been found, and it might imply that Yijing's version did not receive a great deal of attention in Dunhuang.

All of these translations have the same structure. The sütra begins by describing Medicine Buddha's Twelve Great Vows and the Pure Land of Lapis Lazuli, which is established as a result of the vows. The Twelve Great Vows include: 1) to illuminate countless realms with his radiance, enabling anyone to wholly resemble him, 2) to show the dawn to the beings who are in darkness through his light of lapis lazuli, 3) to provide the sentient beings with all that they need, 4) to correct heretical paths and guide beings toward the path of Mahāyāna, 5) to cause beings follow the pure conduct, 6) to heal beings born with deformities, illness or other physical sufferings, 7) to relieve the destitute and the sick, 8) to help women who suffer from their female form to be reborn as men, 9) to help beings escape from mental afflictions and delusions, 10) to help the oppressed be free from bitterness, 11) to relieve those who are tormented by hunger and thirst, and 12) to help clothe any beings who are poor and irritated by cold, heat, flies and mosquitoes. ${ }^{17}$ To summarize, the Twelve Great Vows are to satisfy the

16 T. no. 451, vol. 14.

17 Referred to the translation by Minh Thanh and P.D. Leigh, Sütra of the Medicine Buddha: 
basic material and spiritual needs of sentient beings.

After the Twelve Great Vows, the sütra explains how to perform the rituals to invoke Medicine Buddha's spiritual power. The rituals include the sincere recitation of Medicine Buddha's name and the performance of lighting lamps to the sütra or an image of Medicine Buddha. By performing the rituals, believers pray for the grace of Medicine Buddha to avoid the Nine Forms of Violent Death, which are 1) untimely death through ignorance, confusion and reliance on wrong, inverted views, 2) execution by royal decree, 3) losing one's vitality to the demons through hunting, gambling, debauchery, drunkenness or extreme dissipation, 4) death by fire, 5) death by drowning, 6) being devoured by wild animals, 7) falling off a mountain or a cliff, 8) death by poison, incantations, evil mantras or demons-raised-from-the-dead, and 9) death by hunger or thirst from lack of food and water. The last section of the Sütra of the Medicine Buddha mentions the Twelve Generals, the protectors of the cult of Medicine Buddha, who heard Śākyamuni's preaching about the wonders of Medicine Buddha. Each of them commands seven thousands troops and vows to protect the people who worship Medicine Buddha and uphold the sütra.

There is a slight difference between Yijing's version and the other four. His

Translated and Annotated under the Guidance of Dharma Master Hsuan Jung (North Hills: International Buddhist Monastic Institute, 2001). 
version states that the merits are to be gained by reciting special dhäraniss (a type of ritual speech, or a mnemonic device to encapsulate the meaning of the Buddha's words). This reflects the esoteric nature of Yijing's translation. In conclusion, the numerous translations show the importance of the Medicine Buddha cult for the Chinese Buddhists.

\section{The Iconography of Medicine Buddha in the Texts}

Overall, the five translations never mentioned the iconography of Medicine Buddha. Representations of Medicine Buddha's images are various in body gestures, hand gestures, or the attributes. Thus, the images of Medicine Buddha have no constancy, and the representation varies according to time and location. ${ }^{18}$ However, the artists still established certain features to represent the transformation tableaux of the Sütra of the Medicine Buddha. Although there are minor differences, all the translations emphasize Medicine Buddha's healing power to cure illness and help all suffering beings. The artists depict this concept through the main ritual for praying for Medicine Buddha's help, which is the ceremony of burning seven lanterns and hanging the five-

18 Donohashi Akio, "Dunhuang de yaoshi jingbian yu riben de yaoshi rulai xiang," Dunhuang guoji taolunhui wenji (Liaoning: Liaoning meishu, 1987), p. 384. 
color, forty-nine foot long banner. ${ }^{19}$ In addition, the artists illustrate Medicine Buddha's "Pure Land" as described in the texts as being as gorgeous as the popular Western Pure Land, except that the floor of his Pure Land is made of the precious blue stone, lapis lazuli.

Medicine Buddha is guarded by the Twelve Generals. In Śrīmitra's version, the Twelve Generals are called the Twelve Heavenly Kings. ${ }^{20}$ But in the later translations, they are named the Twelve Yakșa Generals. ${ }^{21}$ Since the Yakṣa 夜叉 is a malevolent spirit, the expressions of the Twelve Yakșa Generals are usually very fierce and look like warriors, armored and armed. The Twelve Yakșa Generals are the warrior deities who listened to the Sütra of the Medicine Buddha and pledged to aid all sentient beings to free them from their pain and suffering. They are Medicine Buddha's exclusive guardians. These specific descriptions in the Sütra of the Medicine Buddha were known and used by the artists.

Textual and Pictorial Resources from Dunhuang

19 For example, see Xuanzang's translation, T. no. 450, vol. 14, p. 407c.

20 T. no. 1331, vol. 21, p. 536a.

21 T. no. 450, vol. 14, p. 408a-b. And T. no. 451, vol. 14, p. 416 b. 
The large number of scriptures found in Cave 17 of Dunhuang proved that the Medicine Buddha belief thrived even more after the Middle Tang period. Cave 17 of Dunhuang is known as "the Cave Library" since it has contained thousands of scrolls. In the cave, almost three hundred scriptures were found that are related to the Sütra of the Medicine Buddha and spells. One of the earliest was written in 533 CE. Many sūtra copies include the prayers on curing, safety, or longevity for the copyist/donor himself or his relates in the end. Apparently, the purpose of copying the Sütra of the Medicine Buddha was to pray for the benefits of this life. On the other hand, more than ninety transformation tableaux of the Sütra of the Medicine Buddha were painted in the Dunhuang caves, and most were created in the Middle Tang and the following periods. The study of the mural paintings from the Middle Tang and the Late Tang periods should not be ignored, because of their large number and also because of the religious meanings and functions behind them.

\section{Research Review}

Despite the large number of paintings and copies/manuscripts of the Sütra of the Medicine Buddha that have survived from Dunhuang, there are only limited studies of the paintings of Medicine Buddha in Dunhuang. Matsumono Eiichi compiled almost all the transformation tableaux of the Sütra of the Medicine Buddha in Dunhuang and 
excerpted related texts. ${ }^{22}$ Akio Donohashi and Luo Huaqing discussed the compositional development of these transformation tableaux. Initially, the pictorial design of Medicine Buddha's Pure Land borrows from the Western Pure Land, the paradise of Amitabha Buddha. ${ }^{23}$ Recently, Lee Yu-min noticed that during the High Tang period, the Medicine Buddha murals were usually depicted on the wall opposite to the Western Pure Land to emphasize the two comparable Pure Lands of the East and West (one cult benefits the temporal life, and the other benefits the afterlife). Lee also studied the copies of the scriptures found in the Dunhuang Library. These hand-written copies reveal that the essence of the cult of Medicine Buddha at Dunhuang is to pray for the curing of illness and for longer lives. ${ }^{24}$ Yao Chongxin claimed that the cult of Medicine Buddha at Dunhuang can be seen as a cult focused on the benefit of this life, instead of the pursuit of rebirth in the Pure Land. He pointed out that at Dunhuang, the occurrences of the depictions of Medicine Buddha's paradise are second only to that of Amitābha's Pure Land. ${ }^{25}$ Could the Medicine Buddha murals in Dunhuang caves reflect

22 Matsumoto Eiichi, "Yakushi jyōdo hensō no kenkyū," Kokka 44, no. 6, 7, 9 (1934), pp. 204-209, 235-240, 262-266.

23 To borrow the stereotype from the Western Pure Land corresponds to the textual description, "Medicine Buddha's Pure Land is comparable in everything to the Western Pure Land." Donohashi, see footnote 18. And Luo Huaqing, "Dunhuang bi hua zhong de dong fang Yaoshi jing tu bian," Dunhuang yenjiu 19, no. 5 (1989), p. 10.

24 Lee Yu-min, “Dunhuang yaoshi jingbian yenjiu,” Gu gong xue shu ji kan 7, no. 3 (1990), pp. 1-40.

25 Yao Chongxin, "Jing tu de xiang wang hai shi xian shi de xi ji? --zhong gu zhong guo yaoshi xin 
the character of this cult? The connection between the pictorial works and the scripture copies has not been discussed in previous studies.

\section{The First Transformation Tableau of Medicine Buddha in Dunhuang}

From the Tang Dynasty, the earliest example of Medicine Buddha pictures is the mural on the east wall of Cave 220 (Fig. 1). ${ }^{26}$ The excavation of this cave was completed in $642 \mathrm{CE}^{27}$ The mural on the east wall depicts seven Buddhas, standing on the main platform which looks like it is covered with dark-colored lapis lazuli. This corresponds to the description in the text of Medicine Buddha's Pure Land, where lapis lazuli is used to cover the floor. ${ }^{28}$ The deep blue lapis lazuli might be explained as the magic stone from Mount Meru rather than glass made by fire. ${ }^{29}$ Each Buddha has a lotus-like censer in the front. In the front platform are dancers and heavenly figures

yang nei han zai kao cha," Zhong guo dunhuang tu lu fan xue hui cheng li san shi zhou nien guo ji xue shu yen tao hui lun wen ji (2013), pp. 343-359.

26 Dunhuang yen jiu yuan, et. al. ed., Dunhuang shi ku yi shu 敦煌石窟㙯術 (Nanjing: Jiangsu mei shu, 1996), vol. 3, pl. 27.

27 The inscription written on the shelf of the central pillar records the completing year of Cave 220. See Luo, p. 11.

28 For example, see Dharmagupta's version, T. no. 449, vol. 14, p. 402a.

29 Birnbaum, p. 65. 
worshiping a tiered pillar or a multi-layered lamp in the center, and some bodhisattvas lighting two triple-layered cartwheel lamps on both sides. To light the tiered lamps is the essential part of the ritual to worship Medicine Buddha. On the two side platforms, there are groups of musicians and the Twelve Generals. The Twelve Generals are depicted in a much bigger size than the musicians. The proportions of the figures show the hierarchical relation between these figures. These generals with fearful, monsterlike face and crowned by a snake or a dragon are the Twelve Yakș $a$ Generals mentioned in Dharmagupta's version. ${ }^{30}$ The name "yakșa" in the Indian tradition means fierce spirit-beings and implies that the appearance of these generals does not look human. Thus the important visual features, such as the lapis lazuli floor, the lamps, and the Twelve Yakșa Generals, have been shown in the first Medicine Buddha mural in the Tang Dynasty.

Even with the previously mentioned motifs, the overall composition of this mural in Cave 220 remained simple. There were lamps in the foreground, and the main figures were aligned in the middleground. This arrangement was retained from the murals of preaching assemblies with Medicine Buddha and his attendants in the Sui Dynasty, such as the murals in Cave 417 and Cave 433 (Fig. 2a, 2b). The difference between Cave 220 and the Sui examples is the number of Medicine Buddha images. The mural

30 T. no. 449, vol. 14, p. 404b. Also seen in Xuanzang's translation, T. no. 450, vol. 14, p. 408 a. 
in Cave 220 is a special and isolated example with seven standing Buddhas depicted.

The textual source of this seven-Buddha motif shown on the mural has been debated. Among the five translations, only the latest one, Yijing's version, is titled "seven Medicine Buddhas" and literally corresponds to the seven-Buddha motif of this mural. However, Yijing translated the sütra in $707 \mathrm{CE}$, later than $642 \mathrm{CE}$, the year Cave 220 was completed. This translation had no chance to influence the design of the mural in Cave 220.

On the other hand, Dharmagupta's translation mentioned the healing effect of chanting the Sütra of the Medicine Buddha in front of seven Buddha images with seven lamps and a banner of forty-nine inches long. ${ }^{31}$ Ning Qiang argued that the sevenbuddha motif on this mural was used for the practical curing rituals performed by the donors, the Zhai Family. ${ }^{32}$ There is insufficient evidence to support that the family had ever held healing rituals inside Cave 220, but the seven-buddha motif is certainly related to the healing power of Medicine Buddha. Seven and forty-nine are significant numbers in Buddhism. Sākyamuni took seven steps upon birth; forty-nine refers to the

31 Luo, p. 12. Also see Lee, p. 11. The section in Dharmagupta's translation, see T. no. 449, vol. 14, pp. 430c-404a. Xuanzang's translation includes the similar section as well, but the translation date is in $650 \mathrm{CE}$, later than the time Cave 220 was completed.

32 Qiang Ning, Art, Religion and Politics: Dunhuang Cave 220 (Cambridge: Harvard University, 1997), pp. 23-25. 
intermediate state between incarnation durations. ${ }^{33}$ The icon of seven Medicine Buddhas in Japan is also a subject discussed by scholars. ${ }^{34}$ It appears that the Japanese artists used the Śākyamuni's motif of "seven Buddhas of the past in the mandorla" to represent the seven Medicine Buddhas. Whether the interpretation of the Japanese iconography is tenable or not, for Chinese images, the three/five/seven Buddhas in the mandorla have been the common decoration for every Buddha since the fifth century. The acceptance of the seven Medicine Buddhas might not have been established when Medicine Buddha became popular in the seventh century. The textual source and functionality of the Cave 220 mural are still being questioned.

The Western Pure Land (Amitābha Buddha's land, named Sukhāvatī, which means the Pure Land of Ultimate Bliss) is depicted on the opposite wall facing the mural of the Medicine Buddha tableau. The placement creates the four-direction universe for the interior space of Cave 220 and enhances the relationship between the Western and the Eastern Pure Lands. The pairing of the paintings of these two Pure Lands can also be found in the record written by Zhang Yanyuan 張彥遠. In his famous book, Record of Famous Paintings of Succeeding Dynasties (Ch. Lidai Minghua Ji 歷代名畫記), he

33 Birnbaum, pp. 56-57.

34 Donohashi, pp. 389-390. Also see Yui Suzuki, "the Aura of Seven: Reconsidering the Shichibutsu Yakushi Iconography," Archives of Asian Art 60 (2010), pp. 19-42. 
noted that the Western Pure Land and the Eastern Pure Land were painted on either side of the incense burner in Zhaocheng 昭成 temple in Luoyang, the secondary capital of Tang. The habit of depicting the Western and Eastern Pure Lands as a pair was continued until about the thirteenth century. ${ }^{35}$ Pairing with the Western Pure Land makes a strong contrasting image: the East and the West, the benefit for the temporal life and the afterlife. ${ }^{36}$ The location of Medicine Buddha's Pure Land is in the east, corresponding to the traditional Chinese concept that the east is the direction of growth. The existing idea of vitality enhances the essential benefit of the cult of Medicine Buddha, such as healing, avoiding sufferings, and prolonging lives. Before the Tang Dynasty, people used to depict the Medicine Buddha tableaux in the location related to the Maitreya tableaux, which was the mainstream Buddhist cult before the Tang Dynasty. $^{37}$

The Tableaux of Medicine Buddha Inspired by the Tableaux of Western Pure Land The first building-complex-style transformation tableau of the Sütra of the

35 Lee, pp. 11-12.

36 Yinshun, Jing tu xin Iun (Xindian: Mile, 1982), pp. 347-348.

37 Lee, pp. 10-11. 
Medicine Buddha showed up in Cave 148 (Fig. 3). Cave 148 is a big transverse rectangular cave, completed in $776 \mathrm{CE}$ at the end of the High Tang period. Excavated by the locally prominent Li Family, Cave 148 has various subjects on its murals surrounding the main nirvana Buddha image. There are thousand-buddha motifs on the ceiling, the illustrations of the Sütra of Maitreya (on the south wall), the Sütra on Deva's Inquiries (on the north wall), and the Sutra of Requiting Kindness (on the ceiling of the entering passageway), and the esoteric forms of Avalokiteśvara (on the east wall), Amoghapāśa (on the north wall) and Cintāmanichakra (on the south wall) on the side walls. Scholars have tried to unify these subjects and to interpret the meaning of the design of Cave $148 .^{38}$ While there is no simple unifying theme for the subjects shown in Cave 148, this enormous cave does reflect the Li Family's attitude toward Buddhism. They worshiped Buddhism with enthusiasm and spared no effort to collect stencils from the capitals. ${ }^{39}$

In Cave 148, the Western Pure Land and the Eastern Pure Land were painted on the two side walls (on the south wall and the north wall, respectively). Unlike the Pure Land paintings in Cave 220, which connected with each other only by the design of

38 Sonya Lee, Surviving Nirvana: Death of the Buddha in Chinese Visual Culture (Hong Kong: Hong Kong University Press, 2010); Gong Weizhang, Niepan, jingtu de diantang: Dunhuang Mogaoku di 148 ku yenjiu (Beijing: Minzu, 2004).

39 Gong, pp. 48-61, 224-228. 
their relative positions, the compositions of these two illustrations are similar. The main Buddhas were put in the center of the painting as the main icon, surrounded by their retinue and companions. Above the main figures are the structure of the heavenly palaces. Upon the clouds are Buddhas and music instruments. The foreground shows the lotus ponds and several smaller platforms connected by bridges, with the main figures sitting on central platforms. Dancers, musicians, and worshiping bodhisattvas underline the pleasure and splendor in the Pure Lands. The sense of order pervades these formal, geometric depictions of Pure Lands, and the architectural arrangements reproduce the layout of Tang monasteries and palaces. Most of the Medicine Buddha tableaux in Dunhuang during the Tang Dynasty depict these formal, geometric depictions of Pure Lands.

Beside each illustration, two narrow columns are attached on either side. Each column depicts ten or more scenes from top to bottom. This same composition attests to the fact that the transformation tableaux of the Sütra of the Medicine Buddha borrows the tableaux of Amitāyurdhyāna Sūtra as its prototype. The Amitāyurdhyāna Sütra is about "meditation on Amitāyus," and the practices to contemplate the holy icons and the Sixteen Forms of Meditation would absolve one's sins in his present life. With the emergence of contemplation practices, the Tang artists created the side columns to depict the scenes of the Sixteen Forms of Meditation. This majestic composition of iconic Buddha images in palatial buildings upon a lotus pond had been developed in the 
illustration of the Western Pure Land since the Early Tang period. The murals of the Western Pure Land in Cave 172 and Cave 217 (Fig. 3a) are among two of the earliest examples. The structure of the Western Pure Land was also used to create Maitreya's Pure Land. ${ }^{40}$ The tableau of the Sütra of the Medicine Buddha in Cave 148 used the prototype of parallel orthogonal recession and multiple-point perspective. Two sets of parallel orthogonals were placed symmetrically, meeting on the central axis and focusing on the frontal main icons. Wong said, "focusing on the Buddha as the icon, this convergent multiple-point perspective effectively portrays deep recessional space and an orderly world associated with spiritual purity." ${ }^{41}$ The tableaux of the Sütra of the Medicine Buddha adopted the representation of the Western Pure Land (Fig. 3b), corresponding to the description in the Sütra of the Medicine Buddha: the buildings in the Land of Pure Lapis Lazuli are exactly the same as in the Land of Ultimate Bliss. ${ }^{42}$

The two columns on the two sides depict the Twelve Great Vows and the Nine Forms of Violent Death. Each scene of the Vows and the Deaths is accompanied with an inscription. Gong Weizhang said that these inscriptions were excerpted from the

40 Wong Dorothy C., Dunhuang mile jingbianhua de yanjiu, Master's Thesis in 1985, pp. 235-240.

41 Dorothy C. Wong, "Mapping of Sacred Space," in Philippe Forêt and Andreas Kaplony edit., the Journey of Maps and Images on the Silk Road (Leiden: Brill, 2008), pp. 64-66.

42 Dharmagupta, vol. 14, p. 402a; also seen in Xuanzang, vol. 14, p. 405c 
Sütra of the Medicine Buddha translated by Xuanzang. ${ }^{43}$ However, Tamami Hamada compared these inscriptions with other translated versions. She pointed out that both Śrīmitra and Xuanzang's versions were cited. Moreover, the Medicine Buddha dhāraṇ̄ from Yijing's version was inscribed in a dhāraṇi pillar above the main Buddha. ${ }^{44}$ The textual evidence implies that the designer of this tableau might refer to several translations of the sūtra at the same time.

On the right margin are the scenes of the Twelve Great Vows, made by Medicine Buddha when he was a bodhisattva, to grant all beings healing from every kind of illness. The scenes of the Vows are similar. Each scene depicts Medicine Buddha sitting and preaching on a lotus throne in front of some bodhisattvas or devotees. On the left margin are the scenes of the Nine Forms of Violent Death. The first scene on the top depicts an emaciated sick person lying on a couch, supported by a person behind him. Three robed figures and a heathen hold up the scrolls and chant. Beside the heathen is an altar with flags on the four corners, and the offerings are on the altar. A female dancer is playing a pipa 琵琶, (a musical instrument) and dancing in front of the altar. This scene represents the description of the First Violent Death, which says that "this misled person cannot discern correctly with his own heart, so he asks divinatory

43 Gong, pp. 146-153. Lee, p. 17.

44 Hamada Tamami, "Tonkō bakukōkutsu dai 148 kutsu no yakushi kangyō ni tsuite," Nara bijutsu kenkyū 12 (2012), pp. 117-124. 
questions in his search for good fortune, and he kills all sorts of living creatures to propitiate spirits. He calls the spirits of the waters and begs for blessings, desiring to lengthen his years." 45

Under the scenes of the Nine Forms of Violent Death on the left column is the scene of ritual (Fig. 3c) ${ }^{46}$ It depicts a Buddha image seated inside a hall and three monks sitting aligned next to the image. A layman stands behind the monks, holding a scripture-like object. The servants are putting the offering and the food on the table outside the hall. A long pole with a blowing banner stands in the courtyard. A sevenlayer wheel-like lamp is put in the right hall. This is the scene of monks feasting and praying to Medicine Buddha. The picture corresponds to the description in the Sütra of the Medicine Buddha:

If you desire to deliver a sick person from the pain of disease, you should accept and hold to the eight-fold vows for seven days and seven nights. You should collect together food, drink, and other property and, in accordance with your means, provide a pujja offering to the community of monks. You should worship with a pujja offering that Lord Master of Healing six times during the day and night. Read and recite this sütra forty-nine times. Light forty-nine lamps and make seven images of the form of that Tathagata. In front of each image arrange seven lamps. Make each lamp as large as a cartwheel, and for forty-nine days let their shining light ceaselessly burn. Make a five-colored,

45 T. no. 450, vol. 14, p. 408a: “解奏神明 呼諸䰨鬼雨 請乞福祐 欲冀延年.” Translation is referred to Birnbaum, p. 168.

46 Hamada, Fig. 9. 
variegated banner forty-nine hand-lengths in height. ... Then the sick person will be able to obtain passage through this danger, and he will be removed from the grasp of evil demons. ${ }^{47}$

This scene records the reality of how Tang people observe the ritual, praying to Medicine Buddha to cure their sick relatives. In contrast to the goal of gaining rebirth in the Pure Lands, this ritual with lamps and a banner focuses on benefits for the temporal life. This ritual scene is arranged at the bottom of the side column, closest to the viewers. ${ }^{48}$ This arrangement reminds the viewers of the ritual enacted in their daily lives.

The artists used several pictorial details to distinguish Medicine Buddha's land from the Western Pure Land. The contents of the side columns are different from the two Pure Lands. The scenes of the Sixteen Forms of Meditation and the Twelve Vows and the Nine Forms of Violent Death can be told easily by the devotees who were familiar with the sütras. Furthermore, the Twelve Generals sitting on the two front platforms are the protectors for the Sütra of the Medicine Buddha. Their special appearances are hard to ignore.

In the central top of the mural, a dhärañi pillar was shown in the light cone

47 The text used here is translated by Raoul Birnbaum. See Birnbaum, p. 166.

48 Hamada, p. 124. 
radiating from the top of Medicine Buddha's head. Hamada recognized that the words written on the dhāraṇi pillar are the dhāraṇi from Yijing's translation. ${ }^{49}$ Unlike the preceding translations, Yijing's version emphasizes the merits gained by reciting specific dhāraṇis since it was requested by the Tang Emperor Zhongzong (656-710). Emperor Zhongzong was dethroned by his mother, Empress Wu (624-705), in $684 \mathrm{CE}$ and was saved by the constant invocation of the name of Medicine Buddha. According to Yijing's version, when Medicine Buddha attained enlightenment, he sought to end all diseases and sufferings. He entered into samādhi, and a great light was emitted from his $\bar{u} r n \underline{a}$. From the light resounded the great $d h \bar{a} r a n \bar{l}$, which is the one written on this dhāraṇi pillar. After the dhāraṇī was uttered, illness and miseries were removed from all beings, and they all became peaceful and joyous. ${ }^{50}$ The dhāraṇi pillar in the light cone from Medicine Buddha's head represents a climactic moment in the sütra. From the above we can see that the tableau of the Sütra of the Medicine Buddha in Cave 148 synthesized at least three translations of the Sütra of the Medicine Buddha. In addition, this form of the dhäraṇi pillar is also shown on the top part of the Medicine Buddha's Pure Land in Cave 237, Cave 156, and Cave 18, all of which were painted at a later

49 Hamada, p. 125.

50 T. no. 451 , vol. 14 , p. 414 b-c. 
date. $^{51}$

To sum up, the transformation tableau of the Sütra of the Medicine Buddha in

Cave 148 shows the connection with the Western Pure Land, the esoteric element, and the practical ritual based on the sütra. Futhermore, all beings who recite the Medicine Buddha dhäraṇi and do the rituals would be saved from the Nine Forms of Violent Death. The motifs on this tableau show the strong wish of the donors of Cave 148 to be protected from danger.

Two More Examples on Silk Paintings

The later application of the transformation tableaux of the Sütra of the Medicine Buddha is shown on a silk painting, numbered Stein 36, currently in the British Library (Fig. 4). ${ }^{52}$ This painting was finished in the ninth century, probably some fifty years later than the completion time of Cave 148. The main Buddha holds a medicine bowl in his left hand, which contains the medicine for curing all sentient beings. The medicine

51 Hamada, p. 127. In the later cases, the dhāranī pillars are on the rising clouds, not in the radiance. The words written on the dhāraṇi pillars are unclear and unable to confirm to be dhāraṇī. But they are similar to the dhāran̄i pillar shown on the mural in Cave 148.

52 sous la direction de Jacques Giès, et al., Les Arts de l'Asie centrale: la collection Paul Pelliot du musée national des arts asiatiques -- Guimet (Paris: Réunion des musées nationaux,1995), vol. 1, pl. 16. 
bowl has emerged as one of Medicine Buddha's iconographical traits since the ninth century. ${ }^{53}$ The new iconography of Medicine Buddha might come from the text of the esoteric Medicine Buddha sūtra, the Ritual for the Worship of the Master of Healing Tathāgata (Ch. Yaoshi rulai nien song yi gui 藥師如來念誦儀軌) translated by Amoghavajra (Ch. Bukong 不空, 705-774). ${ }^{54}$ The text relates:

"Bhaișajyaguru grasps with his left hand a medicine vessel, which is also named the Priceless Pearl. With his right hand he makes the gesture known as bhümisparśa mudrā. He wears the monk robe and sits in the meditation position on the lotus throne. Below the throne are the Twelve Deva Generals."

The Twelve Generals sit on the platforms below the central platform, forming a triangle with Medicine Buddha in the center of the painting (Fig. 4a, 4b). They are described in detail, and each is dressed in his own helmet and armor. They are distinguished from the retinue of unarmed heavenly figures. In addition, the attendant bodhisattva on the right of Medicine Buddha holds a pilgrim's staff, which became another attribute of

53 Lee Yumin, p. 18, and see Dunhuang shiku yishu, vol. 4, pl. 127. The same change happened in Japan in the ninth century as well. "Ninth-century Yakushi Buddhas from Kokusekiji, Shin Yakushiji, and Shōjiji all hold medicine jars, whereas Yakushi Buddhas prior to the ninth century, such as those from Hōryūji and Yakushiji, do not have any." Referred from Yui Suzuki, "The Aura of Seven: Reconsidering the Shichibutsu Yakushi Iconography," Archives of Asian Art 60 (2010), pp. 31-32.

54 Matsumoto, Kokka 44, no. 6 (1934) pp. 178-179.

55 T. no. 924 A, vol. 19 , p. 29 b. 
Medicine Buddha in the contemporary period. A Japanese text mentions that there were Chinese paintings depicting Medicine Buddha holding a jar and a pilgrim's staff. ${ }^{56}$ The mural in the tenth-century Cave 6 depicts a Medicine Buddha holding a medicine jar with his left hand and a pilgrim's staff with his right hand. ${ }^{57}$

The two side columns depict the Twelve Great Vows and the Nine Forms of Violent Death. These scenes are similar to the scenes arranged vertically in the illustration in Cave 148, on the right with the Twelve Great Vows and on the left with the Nine Forms of Violent Death. Every scene on the column is accompanied by an inscription, and the texts of the inscriptions are based on Xuanzang's translation, which was the most popular at that time. ${ }^{58}$ Matsumoto investigated the scenes on the two side columns in detail. ${ }^{59}$ The first four inscriptions of the Twelve Great Vows are not arranged in a standard order. In Stein 36, the text of the first inscription belongs to the Third Vow and combines several sentences from the Fourth Vow. The text of the First Vow is written in the second frame. The text of the Second Vow is written in the third frame. In the fourth frame are the Fourth Vow, attached to the rest of the words of the

56 The Japanese text is from Anthology of A, Sa and Va (阿娑縛抄), “㕛有唐本持缽錫杖.”

57 Matsumoto, Kokka 44, no. 6 (1934), p. 179.

58 Lee, p. 17; Donohashi, p. 388.

59 Matsumoto, Kokka 44, no. 7 (1934), pp. 205-208. Also see in Yen Chih-hung, Bhaișajyaguru at Dunhuang, PhD diss. (University of London, 1997), pp. 174-178. 
Third Vow. The fifth to the ninth inscriptions of the Vows are written in order, but the inscriptions of the other three Vows have been lost.

The first four inscriptions were written randomly, but the first four scenes were depicted in order. The scene of the Fifth Vow does not exist in Stein 36 painting, so the text of the Fifth Vow accompanies the scene of the Sixth Vow, and so on. The following describes the scenes of the Twelve Vows: 1) a bodhisattva putting his hands together and kneeling in front of a Buddha sitting on a lotus throne. The scene might represent "to illuminate the light to everything" from the First Vow. 2) Only a Buddha sitting on the lotus throne exists. 3) Two laymen putting their hands together in front of the Buddha. 4) Two laymen and a monk in front of the Buddha. The appearance of the monk shows the Fourth Vow, to inspire beings toward the path of Mahāyāna. 5) A hunchback and a cripple face toward the Buddha, and a healthy being stands between them and the Buddha. It's not the Fifth Vow but the Sixth Vow, to heal beings born with deformities. 6) A sick figure lies on the bed in front of the Buddha. The scene represents the Seventh Vow, to heal the sick. 7) A woman kneels down and turns to a man in front of the Buddha. It is the scene of the Eighth Vow, to help women to be reborn as men. 8) The scene is not clear but might be the Ninth Vow, to heal the mental afflictions. The scenes below are broken.

The left column illustrates the Nine Forms of Violent Death. The texts written 
within the eight rectangular frames correspond to Xuanzang's version. Within the first frame are the words of the First and the Second Form of Violent Death. The bottom of the painting is broken so only the first eight forms of the Violent Death remain. 1) A sick man sits on the bed, supported by his wife. Two monks and two laymen sit beside the bed, and each holds a scroll of sütra (chanting). 2) A naked person gets whipped, the execution of the law. 3) Two scenes. The first shows a man holding a bird and carring a hound (Fig. 4c), and the second shows a naked person whose face is covered by a white cloth and whose hands are fastened pulled by a nude demon. The two scenes represent the text, "hunting for pleasure, then the fiend comes and snatches his vigour." 4) A figure on fire. 5) A drowning figure. 6) A figure chased by two fierce animals. 7) A figure falling down from as cliff (Fig. 4d). 8) A person killed by a resurrected corpse. 9) Destroyed. The end of this side column has broken, and it is impossible to know whether below the Nine Forms of Death is the scene of ritual and feasting, like the tableau in Cave 148.

Both the Stein 36 silk painting and the murals in Cave 148 have esoteric elements. The motifs of the murals in Cave148 include Thousand-Armed Avalokiteśvara, Cintāmaṇichakra, and Amoghapāśa. The three esoteric Avalokiteśvaras are also shown on the right top, right bottom, and left bottom of the Stein 36 painting respectively. In addition, there is one more esoteric bodhisattva, Thousand-Armed Mañjuśrī, in Stein 36. Matsumoto adduced that Mañjuśrī serves as the primary interlocutor in the Sütra of the 
Medicine Buddha. ${ }^{60}$ But Lee found commonality between these esoteric bodhisattvas and Medicine Buddha. ${ }^{61}$ To practice the ritual for Thousand-Armed Avalokiteśvara is to avoid the various sicknesses, ghost poison (Ch. guidu 鬼毒), and calamities. ${ }^{62}$ To recite the mantra of Cintāmaṇichakra can remove the hindrances caused by sin and free one from suffering. ${ }^{63}$ Cintāmanichakra also saves people from falling off a cliff, being burnt by fire, being drowned, and all disasters from ferocious beasts, weapons, or fetters. ${ }^{64}$ These calamities are similar to the Second, Fourth, Fifth, and Sixth Forms of Violent Death. To recite the dhāraṇī of Amoghapāśa can gain twenty kinds of merit, including safety from sickness, robbery, starving, fire, drowning, falling from a cliff, evil calamity, and cursing. ${ }^{65}$ In praying to Thousand-Armed Mañjuśrī, one can ask for peace and prosperity of the country and longevity for the king and queen. ${ }^{66}$ In sum, these esoteric bodhisattvas and Medicine Buddha share similar characteristics, protecting the devotees from various calamities. Their similarity with Medicine Buddha

60 Matsumoto, Kokka 44, no. 7 (1934), pp. 204-205.

61 Lee, pp. 18-19.

62 T. no. 1059, vol. 20, 105b. 千手千眼觀世音菩薩治病合藥經

63 T. no. 1085, vol. 20, 204b. 觀自在如意輪念誦儀軌

64 T. no. 1085 , vol. 20,204 c.

65 T. no. 1092, vol. 20, 228b-c. 不空羂索神變真言經

66 T. no. 1177A, vol. 20,751b. 大乘瑜伽金剛性海曼殊室利千臂千缽大教王經 
should be the reason why they become the motifs depicted in Stein 36 painting.

Another silk painting made in the same period is preserved in the National Museum in New Delhi (Fig. 5). ${ }^{67}$ The main Buddha, Medicine Buddha, has the same iconography as the one in Stein 36, with his right hand in the gesture of the abhaya mudrā, granting fearlessness, and the left rests in the lap with a medicine bowl. The architectural complex is simpler than the buildings in Stein 36, and the number of the retinue is fewer. Medicine Buddha is flanked by the Bodhisattva of Sunlight with his two acolytes on the right and by the Bodhisattva of Moonlight again accompanied by his two acolytes on the left. At the bottom, only a portion of the Twelve Yakșa Generals remains with five generals' faces and big glaring eyes. The two margins on the right and the left are the Twelve Great Vows and the Nine Forms of Violent Death. The rectangular frames assigned to the scenes in the margins are empty with no inscriptions. According to the style and the content, this silk painting can be dated to the ninth century.

On the right margin with the Twelve Great Vows, there only remain one Medicine Buddha's head and two female figures. On the left side with the Nine Forms of Violent Death remain several disordered scenes. 1) The top scene is similar to the top scene in

67 Matsumoto, Kokka 44, no. 7 (1934), p.209. The plate is from Lokesh Chandra and Nirmala Sharma, Buddhist paintings of Tun-Huang in the National Museum, New Delhi (New Delhi: Niyogi Books, 2012), pl. 22. The catalog introduction of pl. 22 is also referred, p. 100. 
Stein 36, depicting the kneeling bodhisattva in front of the lotus throne. 2) The second scene depicts a man and a woman beside a cauldron as a red haired demon stretches out his hand towards them. The scene is related to the Third Form of Violent Death, and people who are lascivious and alcoholic. 3) The third scene is drawing the Fifth Form of Violent Death, a drowning man. 4) The fourth scene is the Third Form of Violent Death and similar to the scene in Stein 36. A man whose face is covered by white cloth and whose hands are fastened is pulled on a tether by a nude demon, corresponding to the text: a man on a high seat who is being taken away by a demon. 5) The fifth scene is about the First Form of Violent Death and similar to the one in Stein 36. There is a sick man to whom two monks read from scrolls. The man cannot procure a doctor, so he has a monk read the sütra. 6) The sixth scene is the Eighth Form of Violent Death, a man getting poisoned or cursed by a demon, and it represents a similar theme as the scene in Stein 36. The scene shows a man kneeling on the platform as a demon rushes towards him. 7) This hunting scene is the third scene related to the Third Form of Violent Death on this painting, depicting a man with falcon on wrist. 8) This scene represents the Fourth Form of Violent Death, a man encircled by flames. 9) Destroyed.

Through comparison, we find similar scenes in the side columns of the tableau in Cave 148 and the two silk paintings. However, some of the scenes were not arranged in the same order as mentioned in the sütra. Some of the inscriptions were missed or combined, or do not match the pictorial scenes, such as the Vows in Stein 36 and the 
Nine Deaths on the New Delhi painting. The similarity between these three cases implies that they may all referred to similar manuscripts. The disorder and the missing of the scenes probably resulted from the misinterpretation of the manuscripts.

\section{Clues from the Drafts and Sketches}

The reverse side of S. 2544 scroll is the handwritten version of the inscriptions, including the inscriptions for the transformation tableaux of the Western Pure Land and the Sütra of the Medicine Buddha. The words for the tableaux of the Sütra of the Medicine Buddha were written in sixty lines, selected from Xuanzang's version, but the sentences were modified, cut off, and connected randomly. Wang Huimin thought that the order of the sentences written on S. 2544 was arranged for the mural production. ${ }^{68}$ But in the case of Cave 148, we can see that the scenes and inscriptions on the side columns are in order.

The reverse side of manuscript P. 3304 has several sections of inscriptions. The third and the fifth paragraphs are the inscriptions for the tableaux of the Sütra of the Medicine Buddha. The third section has forty three lines of texts taking from Srīmitra's

68 Wang Huimin, "Dunhuang yi shu zhong de yaoshi jingbian bang ti di gao jiao lu," Dunhuang yen jiu 1998, no. 4 (1998), p. 12. 
version. ${ }^{69}$ The fifth section is from Xuanzang's version but lacks the text on drowning and most of the Vows. ${ }^{70}$ It shows that Xuanzang's version was not the only translation used at Dunhuang and that the inscriptions in Cave 148 were acquired from multiple versions.

P. $2868 \mathrm{v}$ is an ink sketch on the reverse side of a Daoist sütra (Fig. 6). ${ }^{71}$ The ink lines are drawn freehand, and the description of each scene is simple. The scenes are marked by numbers. Apparently, P. 2868v is a guide for making a larger painting. There are three sections of scenes. On the right part are three rows of twelve scenes, and each scene depicts one Buddha worshiped by several laymen or monks. On the right part are the Twelve Vows. The left part is separated into two rows. There are four scenes on the inner row (from the bottom to the top). 1) The scene marked number one depicts a sick man in bed, surrounded by people, and a fiend stands by. It is the First Death. 2) The scene marked number two paints a figure chased by beasts. It is the Sixth Death. 3) The scene marked number three is a drowning man and shows the Fifth Death.

4) The scene marked number four depicts a figure whipping another, and it is the Third

69 Wang Huimin, p. 16.

70 Wang Huimin, "Dunhuang yi shu zhong de yaoshi jingbian bang ti di gao jiao lu bu yi," Dunhuang yen jiu 1999, no. 4 (1999), p. 161.

71 The title of the Daoist sūtra is "Ten zun shuo sui yuan wang sheng zui fu bao dui ci shuo yu xiu ke wen miao jing 天尊說隨願往生罪福報對次說預修科文妙經.” The plate is downloaded from the database of International Dunhuang Program. 
Death. On the outer row: 5) The scene marked number five is a man on fire, the Fourth Death. 6) The scene is a monster riding on a beast and a man worshiping the monster. It is another part of the First Death. 7) The scene is the Second Death, a kneeling man waiting for his execution. The Seventh Death, falling the cliff, and the Eighth Death, getting poisoned by a fiend, do not exist on P. 2868v. If P. $2868 \mathrm{v}$ was truly used as the guide for mural or silk paintings, the features on P. 2868v explain many aspects. For example, the scenes of the Twelve Vows usually look similar, composed with a Buddha and certain worshipers. On the other hand, the scenes of the Nine Forms of Violent Death were not arranged in the order in the text but in the order in the manuscript.

The middle section of P. $2868 \mathrm{v}$ depicts the scene of the ritual and the feast. In a hall inside a yard, a pole with the spiritual banner is erected. Beside the pole is a multiple tiered lamp. Under the eaves are two people sitting and eating. One servant holds the offering. The other four figures stand in the yard with a jar and a sheep. Sha Wutien conjectured that the scene with animals represents the action of releasing animals. Compared to the size of the scenes of the Twelve Vows and the Nine Forms of Death, the scene of ritual and feast was valued by the producer of the sketch. A mural panel in Cave 468 which is completed in the Middle Tang depicts clearly the scene of ritual and feasting (Fig. 7). The composition and the content of this panel are similar to the middle part of P. 2868v. The panel was separated into the top, middle, and bottom sections by architecture. The top section is feasting monks: two monks sit under the 
eaves, and servants handle the offerings in the yard. The middle section is worshiping Medicine Buddha by a multiple tiered lamp. The bottom section might depict releasing animals outside the architecture.

Beyond Dunhuang, very few transformation tableaux of the Sütra of the Medicine Buddha remain. The Niche 96 at the Qianfozhai at Anyue, Sichuan, dated 724, is one of them and is carved in relief (Fig. 8). ${ }^{72}$ The tableau is a composition of Medicine Buddha, flanked by his retinue, the eight Mahābodhisattvas, ${ }^{73}$ and the Twelve Yakșa Generals along the base of the niche. The sides of the niche show the Twelve Vows and the Nine Deaths in low relief, but the Vows are on the left and the Deaths are on the right, reversing the arrangement shown in the murals and silk paintings in Dunhuang. The scenes are arranged by the brick pattern instead of the column pattern in Dunhuang. On the wall to the right of Medicine Buddha remain an imbecile, a blind holding a staff, a hunchback, a woman, and a harmonious family, representing the Twelve Great Vows. On the wall to the left of Medicine Buddha are the scenes of encountering a tiger, corporal execution, being poisoned, being voracious and lascivious, being burnt by fire,

72 Suchan, Thomas, the Eternally Flourishing Stronghold: An Iconographic Study of the Buddhist Sculpture of the Fowan and Related Sites at Beishan, Dazu ca. 892-1155, PhD diss., the Ohio State University, 2003, figure 4.27.

73 The eight Mahābodhisattvas guide newly deceased devotees to be reborn in the Western Pure Land. See T. no. 450, vol. 14, p. 406b; T. no. 1331, vol. 21, p. 533a. 
drowning, begging, and fighting. ${ }^{74}$ The scenes are arranged by brick pattern and not arranged in the textual order. These out-of-order scenes of the Vows and the Deaths imply that these tableaux were not used for the ritual since they did no help to recite the sütra. The donation for making these tableaux should be seen as offerings which could gain benefits and protection from Medicine Buddha.

\section{Screen Composition in the Middle Tang and the Late Tang}

About one decade after the completion of Cave 148, the Tang governor lost the control of Dunhuang area to Tubo (the old name for Tibet). Dunhuang was ruled by Tubo for about 60 years (781-848). This period is often called the Middle Tang. From 849 Dunhuang was nominally restored to the declining Tang empire but in fact was ruled by the family of Zhang until 914. This period is called the Late Tang or the reign of Guiyijun 歸義軍(Return to the Allegiance Army) Regime at Dunhuang (848-914). Since communication with Central China was obstructed, there were fewer resources for the sketches of the design in Dunhuang. The form and style of mural paintings changed quickly in this period.

74 Hu Wenhe, "Sichuan mo yai zao xiang zhong de yaoshi bian han yaoshi jingbian," Wenbo 1998 , no. 2 (1998), p. 55. 
The screen type became popular. On a single wall, more than one tableau are painted, gridded by decorative bands. The spatial recession was lost in the smaller, squeezed tableau. The narrow columns on either side became miniatures in a simplified mode. Then, the way to distinguish the juxtaposed illustrations was to intensify the representative pictorial features. For example, the south wall of Cave 154 includes the transformation tableaux of the Sütra of the Medicine Buddha (the one on the left top), the Maitreya Sūtra, the Lotus Sūtra, and the Golden Light Sūtra (Fig. 9). Each tableau is flanked by two columns, and the columns flanking the tableau of the Sütra of the Medicine Buddha each depicts five scenes (Fig. 9a). On the main tableau, all the floors of the platforms and pavilions are painted in a blue-green color, darker than the color used to paint the pond. The blue-green colored floor is based on the description of the Land of Pure Lapis Lazuli in the sūtra.

The more common arrangement in the Middle Tang is to move the multiple-scene columns to the section below the pure-land scene, instead of flanking it. The numbers of the multiple-scene columns were inconstant, and would not be exactly under their relevant illustrations. The murals were separated into upper and lower registers, and the panels of preaching assemblies in the Pure Lands lost the visual connection with the multiple-scene columns. Therefore, it was necessary to make the features of Medicine Buddha's land stand out for recognition. On the right side of the north wall in Cave 112, the tableau of the Sütra of the Medicine Buddha is juxtaposed with other illustrations 
(Fig. 10). Under the crowded retinue is the blue-green floor. Its color is similar to the water pond, giving the background of this illustration an impression of the Lapis Lazuli World. The Twelve Generals are drawn on the front platform, with exaggerated facial expressions (Fig. 10a). The front platform occupies the closest and the most intimate position in the tableau in relation to the viewers. The Twelve Generals are separated into two groups and aligned in two parallel diagonals. On the extending intersection point of the two group of lines is the main image, Medicine Buddha. The visual effect enhances the connection between the Twelve Generals and Medicine Buddha.

The transformation tableau of the Sütra of the Medicine Buddha in Cave 231 is another example possessing the typical motifs of Medicine Buddha's Pure Land and the ritual (Fig. 11). The tableau uses blue-green color on the floor of the platforms in the Pure Land. On the bottom part of this panel, the Twelve Generals are depicted, (Fig. 11a, now only exist partly). In addition, in the inner corners of the two pavilions in the foreground are two erect long poles, with blowing banners high atop them (Fig. 11b). Each of the two blowing banners is composed of a triangular top part, colorful quadrilaterals, and a long fringe tail. These are the spiritual banners mentioned in the text, with five colors, and used in the ritual of curing the sick. In other words, the motifs of the ritual and the Twelve Generals remain constant in the tableaux of the Sütra of the Medicine Buddha in the Middle Tang. 
During the Late Tang period, the Twelve Generals became a more important visual feature to mark the tableaux of the Sütra of the Medicine Buddha. The former features, including spiritual banners and the narrow columns depicting the Twelve Vows and the Nine Deaths, almost disappeared in the tableaux of the Sütra of the Medicine Buddha. To mark the tableaux of the Sütra of the Medicine Buddha, the Twelve Generals are put on the central platform in the foreground. For example, in Cave 156, which was finished in $861 \mathrm{CE}$, the tableau of the Sütra of the Medicine Buddha is shown with the tableaux of the Sütra of Requiting Kindness and the Sütra of Deva's Inquiries, and the procession of the donor, Lady Song, in the bottom register (Fig. 12). Compared to other motifs in this tableau of the Sütra of the Medicine Buddha, the Twelve Generals are positioned the closest to the viewers. They are separated in the right and left groups as well, worshiping the inscription in the center (Fig. 12a). The text of the inscription does not exist (or was empty from the beginning), but it might be the dhäraṇi mentioned in Yijing's translation. In Yijing's version, the Twelve Generals' names are the dhäraṇi to rescue the sufferings. In cases of illness or danger, people write down the Generals' names on the five-colored banner and tie a knot in the banner. They can untie the knot after they are rescued by the Twelve Generals. ${ }^{75}$

75 T. no. 1331, vol. 21, p. 536a. Also see Arai Keiyo, "Yakushi-kyo no tsutaeru jiuni jinsho," Indo-gaku Bukkyo-gaku kenkyu 20, no. 2 (1972), pp. 264-268. 
The case of Cave 196 is similar to Cave 156 (Fig. 13). Cave 196 was finished in 892-893 CE. The murals on the north wall are separated into two registers. On the upper register, the transformation tableau of the Sütra of the Medicine Buddha is flanked by the tableaux of Avatamsaka Sütra and Maitreya Sūtra. On the lower register are the screen paintings of fifteen attendant bodhisattvas. On the tableau of the Sütra of the Medicine Buddha, the Twelve Generals are also depicted on the central platform in the foreground, and an inscription is in the center between the Twelve Generals (Fig. 13a). The Twelve Generals are not only the guardians of Medicine Buddha, but also the guarantee to the sufferers that they will be rescued. The number twelve relates to the time units. The Twelve Generals protect devotees, all the twelve parts of the day, all the twelve months of the year. Twelve is another number in the Medicine Buddha cycle: his twelve vows. ${ }^{76}$ Therefore, the motif of the Twelve Generals worshiping the dhāraṇi is arranged in the most conspicuous position in the whole tableau of the Siutra of the Medicine Buddha, reminding the devotees of the power of the healing ritual.

Moreover, the motif of the Twelve Generals was shared by medieval Chinese and Japanese as the common iconography of Medicine Buddha. For example, Hōryū-ji (lit. the Temple of the Exaltation of the Law) is a significant group of buildings. The murals

76 Lokesh Chandra and Nirmala Sharma, Buddhist paintings of Tun-Huang in the National Museum, New Delhi, p. 103. 
in Kōndo (lit. the Golden Hall) in Hōryū-ji display the international Tang style that was imported to Japan in the Nara Period. One panel of these murals, which was completed at the very beginning of the eighth century, depicts the Yakșa Generals with the same

appearance of the ones in Cave 220 of Dunhuang, dated in $642 \mathrm{CE}^{77}$ Śrimitra translated the Twelve Generals as the Twelve Divine Kings, but Dharmagupta and Xuanzang translated them as the Twelve Yakșa Generals. The later translation might have inspired Tang artists to depict twelve armed spiritual figures as attendants to Medicine Buddha. The Yakșa Generals on the panel in the Kōndo in Hōryū-ji probably were based on the stencils that were brought to Japan in the early eighth century.

\section{Conclusion}

The development of the transformation tableaux of the Sütra of the Medicine Buddha had three stages during the Tang Dynasty. In the Early Tang period, the new creation of the Eastern Pure Land in Cave 220 reflects the rising of the cult of Medicine Buddha. During the High Tang period, the mature composition of the classic Pure Lands with the side columns is borrowed from the tableaux of Western Pure Land and the tableaux of Amitāyurdhyāna Sütra. The scenes of the Vows, the Deaths, and the

77 Dorothy C. Wong, "Reassessing the Wall Paintings of Hōryūji," in Dorothy C. Wong edits, Hōryūji Reconsidered (Newcastle: Cambridge Scholars Publishing, 2008), pp. 166-167. 
ritual attracted much attention. In the Middle Tang and the Late Tang, there was still the same structure of composition, but the pictorial space is compacted. The illustrations lost the aesthetic creativity and the expression of spatial depth, thus they lost scholars' attention as well. However, the motif of the Twelve Generals is emphasized. The other motifs related to the healing ritual, such as the spiritual banners and multiple tiered lamps, are also shown in the illustrations. In the Late Tang period, the Twelve Generals occupy the most prominent position of the whole mural. The icon of the Twelve Generals worshiping the central inscription is a key to study the practical healing ritual of Medicine Buddha practiced in Dunhuang during the Late Tang period.

Although the transformation tableaux of the Sütra of the Medicine Buddha borrowed the prototype of the Western Pure Land, none of them ignore the essence of this cult: the benefit for this life. From the very beginning of the Medicine Buddha tableau in Cave 220 in the Early Tang, the motifs related to the ritual by which people prayed for cures and safety in the present life were shown clearly. In the examples of the High Tang, such as the mural in Cave 148 and the two silk paintings, the Twelve Vows and the Nine Deaths were depicted in detail. The artists also paid attention to developing the scene of offering and feasting, such as the instances in Cave 148, P. 2868v, and Cave 468. During the Middle Tang and the Late Tang, the space for the side columns became limited, and the scenes related to the this-life benefits disappeared. The absence of the objects related to the healing rite seems to weaken the secular and 
the ritual function of the tableaux. In fact, the secular care is guaranteed by the Twelve Generals. The Twelve Generals gathering in the front platform became the most fixed motif in the tableaux of the Sütra of the Medicine Buddha during the Middle and the Late Tang periods. They would protect the devotees who hold the Medicine Buddha Sütra from the dangers in the world. Overall, the specific elements of the tableaux of the Sütra of the Medicine Buddha are the glorious multi-layer lamps, the wind-blown spiritual banners, the Twelve Generals, and the scenes of the Vows and the Deaths.

The features in the visual representation correspond to the scripture copies that focus on the benefits for this life, such as longevity or eliminating disasters. ${ }^{78}$ Since these materials reveal that the Tang people only asked Medicine Buddha for present benefits, many scholars argue that the cult of Medicine Buddha was secondary to the cult of Western Pure Land. ${ }^{79}$ They believe that the devotional worship of Medicine Buddha did not develop into an independent cult but was practiced along side the worship of Amitābha. Their evidence is that in the texts Medicine Buddha will aid devotees to seek rebirth in the Western Pure Land. However, through studying the details and features of these paintings, we have learned that there were many motifs of the ritual and the benefits gained by holding the Sütra of the Medicine Buddha created

78 Yao Chongxin, pp. 348-352.

79 Qiang Ning, p. 44. Suchan, p. 465. 
in the Tang Dynasty. The works about the Sütra of the Medicine Buddha remain many, and the murals were usually arranged on the wall opposite to that depicting the Western Pure Land. The cult of Medicine Buddha should be equal to the cult of Amitābha. The main demands of the two cults are the guarantees for the present life and the after life. The desires for both were requested reverently by the Dunhuang people who lived in a period of upheaval after the Tubo domination. Even though there is no evidence to prove the art works were used in the physical rituals, these transformation tableaux of the Sütra of the Medicine Buddha show that the cult of Medicine Buddha was important in Dunhuang, and the people did want the benefits and protection for this life no less than to gain rebirth into the Pure Land. 


\section{Bibliography}

Arai, Keiyo. "Yakushi-kyo no tsutaeru jiuni jinsho" 薬師経の伝える十二神将. Indo-gaku Bukkyo-gaku kenkyu 20, no. 2 (1972): 264-268.

Birnbaum, Raoul. The Healing Buddha. Boulder: Shambhala, 1979.

Chandra, Lokesh, and Sharma, Nirmala. Buddhist paintings of Tun-Huang in the National Museum, New Delhi. New Delhi: Niyogi Books, 2012.

Donohashi, Akiho 百橋明穗. "Dunhuang de yaoshi jingbian yu riben de yaoshi ru lai xiang" 敦煌的藥師經變與日本的藥師如來像. Dunhuang guo ji tao lun hui wen ji. Liaoning: Liaoning mei shu, 1987.

Dunhuang yen jiu yuan 敦煌研究院, et. al. ed. Dunhuang shi ku yi shu 敦煌 石窟藝術. Nanjing: Jiangsu mei shu chu ban she, 1996.

--—, ed. Tonkō Bakukōkutsu 敦煌莫高窟. Vols. 2-4. Tōkyō: Heibonsha, 1980-1982.

- - , ed. Dunhuang shi ku nei rong zong lu 敦煌石窟內容總錄. Beijing: Wenwu chu ban she, 1996.

Fan, Jinshi 攀錦詩. "Xuanzang yi jing han dunhuang bi hua" 玄奘譯經和敦煌 壁畫. Dunhuang yenjiu 2004, no. 2 (2004): 1-12.

Giès Jacques, et al.. Les Arts de l'Asie centrale: la collection Paul Pelliot du musée national des arts asiatiques-- Guimet. Paris: Réunion des musées nationaux, 1995.

Gong, Weizhang 公維章. Nie pan, jing tu de dian tang: Dunhuang Mogao Ku di 148 ku yen jiu 涅槃, 淨土的殿堂: 敦煌莫高窟第 148 窟研究. Beijing: Min zu, 2004.

Hamada, Tamami 濱田瑞美. "Tonkō bakukōkutsu dai 148 kutsu no yakushi kangyō ni tsuite" 敦煌莫高窟第一四八窟の藥師經變について. Nara bijutsu kenkyū 12 (2012): 115-133.

$\mathrm{Hu}$, Wenhe 胡文和. "Sichuan mo yai zao xiang zhong de yaoshi bian han yaoshi jingbian" 四川摩崖造像中的藥師變和藥師經變. Wenbo 1998, no. 2 (1998): 51-56. 
Lee, Sonya. Surviving Nirvana: Death of the Buddha in Chinese Visual Culture. Hong Kong: Hong Kong University Press, 2010.

Lee, Yu-min 李玉珢. "Dunhuang yaoshi jingbian yenjiu" 敦煌藥師經變研究. The National Palace Museum Research Quarterly 7, no. 3 (1990): 140.

Liu, Wendong 劉文東. "Da ying bo wu guan cang juan hua 'yao shi jing tu bian' zhi pu sa xing xiang kao xi" 大英博物館藏絹畫《藥師淨土變》之菩薩 形象考析. Mei shu xue bao 2012, no. 4 (2012): 61-66.

Luo, Huaqing 羅華慶. "Dunhuang bi hua zhong de dong fang yaoshi jing tu bian" 敦煌壁畫中的東方藥師淨土變. Dunhuang yenjiu 1989, no. 5 (1989): 5-18.

Mair, Victor. "Records of Transformation tableaux (pien-hsiang)." T'oung Pao 72, Livr. 1/3 (1986): 3-43.

Matsumoto, Eiichi 松本栄一. "Yakushi jyōdo hensō no kenkyū" 薬師净土変相 の研究. Kokka 44, no. 6, 7, 9 (1934): 204-209, 235-240, 262-266.

Ning, Qiang. Art, religion, and politics in medieval China: the Dunhuang cave of the Zhai Family. Honolulu: University of Hawai'i Press, 2004.

Okazaki, Joji, translated by Elizabeth ten Grotenhuis. Pure Land Buddhist Painting. New York: Kodansha Amer Inc., 1977.

Sha, Wutien 沙武田. Dunhuang hua gao yen jiu 敦煌畫稿研究. Beijing: Min zu, 2006.

Soper, Alexander. Literary Evidence for Early Buddhist Art in China. Asocana: Artibus Asiae Publication, 1959.

Suchan, Thomas. The Eternally Flourishing Stronghold: an iconographic study of the Buddhist sculpture of the Fowan and related sites at Beishan, Dazu ca. 892-1155. PhD diss., the Ohio State University, 2003.

Suzuki, Yui. Medicine Master Buddha: the iconic worship of Yakushi in Heian Japan. Boston: Brill, 2012.

---. "The Aura of Seven: Reconsidering the Shichibutsu Yakuhi Iconography." Archives of Asian Art 60 (2010): 19-42. 
Wang, Huimin 王惠民. "Dunhuang yi shu zhong de yaoshi jingbian bangti digao jiaolu" 敦煌遺書中的藥師經變榜題底稿校錄. Dunhuang yenjiu 1998， no. 4 (1998): 12-18.

- - - "Dunhuang yi shu zhong de yaoshi jingbian bangti digao jiaolu bu yi" 敦煌遺書中的藥師經變榜題底稿校錄補遺. Dunhuang yenjiu 1999, no. 4 (1999): 161-163.

Whitfield, Roderick. The Art of Central Asia: the Stein Collection in the British Museum. Vol. 2. Tokyo: Kodansha International in cooperation with the Trustees of the British Museum, 1982.

Wong, Dorothy C. "Reassessing the Wall Paintings of Hōryūji." In Hōryūji Reconsidered, edited by Wong, Dorothy C., 131-190. Newcastle: Cambridge Scholars Publishing, 2008.

---. "Mapping of Sacred Space: Images Of Buddhist Cosmographies In Medieval China." In the Journey of Maps and Images on the Silk Road, edited by Philippe Forêt and Andreas Kaplony, 51-80. Leiden: Brill, 2008.

- - - 王靜芬. "Dunhuang mile jingbianhua de yanjiu" 敦煌彌勒經變畫的研究. MA diss., the Chinese University of Hong Kong, 1985.

Wu, Hung. "What Is Bianxiang 變相? --On the Relationship between Dunhuang Art and Dunhuang Literature." Harvard Journal of Asiatic Studies 52, no. 1 (1992): 111-92.

Yao, Chongxin 姚崇新. "Jingtu de xiang wang hai shi xian shi de xi ji? --Zhong gu zhong guo yaoshi xin yang nei rong zai kao cha" 淨土的㗽 往還是現世的希冀? - - 中古中國藥師信仰內容再考察. Zhong guo dunhuang tu lu fan xue hui cheng li san shi zhou nien guo ji xue shu yen tao hui lun wen ji, 343-359. Beijing, 2013.

Yen, Chih-hung. Bhaișajyaguru at Dunhuang. PhD diss., University of London, 1997.

- - - 嚴智宏. "Tang chao qian qi de yao shi jing bian" 唐朝前期的藥師經變. In 2000 nien Dunhuang xue guo ji xue shu tao lun hui wen ji -shi ku kao gu juan, edited by Dunhuang yen jiu yuan, 88-103. Lanzhou: Gansu min zu, 2003. 
- - - "The Imagined Pure-Lands of Bhaișajyaguru of the Chinese and Tanguts." Journal of Inner Asian Art and Archaeology 2 (2007): 159164.

Yen, Chuan-ying. "The Chai Family Cave --Cave 220 at Tun-Huang Mokao-k'u." Chinese Pen 24, no. 3 (1996): 77-93.

Yinshun 印順. Jing tu xin lun 淨土新論. Xindian: Mile, 1982. 